\title{
A STUDY OF MEDICLAIM POLICYHOLDERS IN INDORE CITY
}

\author{
Dr. Alice Thomas \\ Principal, St. Paul's Institute of Professional Studies, Indore, India \\ Dr.Veena Jha \\ Assistant Professor St. Paul's Institute of Professional Studies, Indore, India
}

\begin{abstract}
Insurance plays an important role in covering risk, anyone can get insured by paying certain known costs in the form of premium and can get their risk covered. Among all the insurance policy, there is a mediclaim policy done for covering illness. The purpose of this research paper is to study about the mediclaim policy holders in Indore city. An empirical study has been conducted in Indore city with 80 respondents to get the required data. The questionnaire result was analysed with chi square test. In the research it was found that age plays an important role in getting information or awareness through internet. This research will help the insurance co. in making marketing strategy.
\end{abstract}

Key words: Insurance, Mediclaim, Role of IRDA, Insurance agents.

Cite this Article: Dr. Alice Thomas and Dr.VeenaJha, A Study of Mediclaim Policyholders In Indore City. International Journal of Management, 10 (1), 2019, pp. 1-6. http://iaeme.com/Home/issue/IJM?Volume=10\&Issue=1

\section{INTRODUCTION}

In this world nothing is certain, only one thing is certain that is uncertainty. Life is full of unforeseen events. So, everyone takes precautionary measures for the unfortunate incidents. Everyone takes secured steps but then also accidents happen, for these types uncertainty we need insurance. Insurance provides us security against risk / losses/death/illness etc. Among different insurance policies, one important policy is "Mediclaim Policy". Mediclaim policy is offered by general insurance co. or non-life insurance co. In India mediclaim policy is done both by private and public insurance co. Mediclaim policy is also known by another name Medical insurance. It provides financial security to the people at the time of hospitalisation for any sickness, as now a days cost of medical treatment is increasing day by day. Mediclaim policyholders can claim hospital bills either by cashless facility in which insurance co. pay directly to hospital or the other way is first you pay your bills, submit it your insurance co. and get reimbursement. 
Sethi Jyotsna and Bhatia Nishwan: Individual mediclaim or hospitalisation benefits policy: - An individual mediclaim or hospitalisation benefit policy provides reimbursement (in Indian currency) of medical expenses incurred towards hospitalisation (anywhere in India) in cases of sudden illness or accident and extends to pre-hospitalisation of 30 days and post hospitalisation of 60 days. The policy is available to any person in the age group of 5 to 80 years. However, children below 5 years but not below the age of 3 months can also be covered as long as one or both of the parents are covered at the same time. The policy carries some additional benefits and may be issue at insurance premium discount on family package, cumulative bonus and health check. The premium paid on the policy upto a maximum of Rs $10,000 /$ - is totally exempt from income tax.

\section{The Institute of Company Secretaries of India:}

Non-Life Insurance or General Insurance; - Conventional classification of G.I.C. has been in 3 branches:-

Fire Insurance, Marine Insurance and Miscellaneous Insurance.

In modern times, it is classified as follows:

Insurance of Person

Insurance of Property

Insurance of Interest and

Insurance of Liability.

Nationalization of General Insurance Business in India:-General Insurance

Business was nationalized in the year 1972, through GIC Act of 1972, through which the general insurance business of private insurers was transferred to GIC having its head quarter at Mumbai. The Govt. of India, through regulation framed 4 subsidiaries to GIC, which were entrusted to control, regulate and develop general insurance business of the country. The subsidiaries with their headquarters are:

- The Oriental Insurance Co.-New Delhi

- The New India Assurance Co. :- Mumbai

- The United India Insurance Co. Chennai

- The national Insurance Co. :-Kolkata

There was a proposal to merge these 4 subsidiaries into one entity at one point of time. Later it was felt that it would be better serve the purpose of competition and freedom of choice if these four companies were made independent from their parent holding co. viz.G.I.C.This has happened.

"Insurance Agent" is a person who has been licensed under section 42 of the Insurance Act, 1938 or under the new IRDA. Agent's Regulation 2000, the person here means:-

- Individual

- A firm;

- A company formed under co. Act 1956(1 of 1956) and includes a banking co. as defined in clause 4 (A) of section 2 of the Act.

Guhati C. Neelam -Premium: - Premium is the consideration paid by the insured to the insurer for the insurance granted under a policy.

Claim Settlement Non-Life Insurance: - The first step is to decide whether the loss is within the scope of the policy. The insurer after verification of the facts of damage and as per the terms of contract will pay the claim.

Agarwal.P.O:-Role of IRDA -The object of IRDA (Insurance Regulatory Development Authority Act, 1999) of an authority to protect the interests holders of insurance policies to 
regulate, promote and ensure orderly growth of the insurance industry and formalities connected there with or incidental there to and further there to amend the Insurance Act, 1938, L.I.C. Act, 1956 and General Insurance Business (Nationalization) Act, 1972. This Act has come into effect from 19.4.2000.IRDA has created an environment conducive for the private sectors to enter into the insurance business. Since then, insurance industry has grown rapidly.

Rationale of the study: Risk is everywhere, in our life. We can fall sick at any time and age of life, for this there is a dire need of mediclaim policy. To know which sources plays an important role in making people aware. As ,Indore city is a commercial city of Madhya Pradesh with potential investors who can invest in med claim policy for security and mental peace as the expenses of hospitalization are increasing day by day. For this purpose this study has been conducted.

\section{LITERATURE REVIEW}

Singh Preeti and Shukla Timiria (2018) discussed that there is a lack of awareness of usefulness of health insurance schemes among the people and penetration level is also low in semi urban area.

Priya A.and Dr.Srinivasan, R. (2018) highlighted in the research that Marketing of health insurance policies are an urgent need of today, which can help people to meet their unto wards expenses arising out of unexpected ailments. Insurance company should record consumer's perception and can make an awareness program among consumers, how health insurance will reduce financial burden during the time of hospitalization.

S.K. Uma and Dr.Vadivel (2017) in their research found that when a patient uses mediclaim policy at the time of hospitalisation charges are more than usual, also provides extra services when they use mediclaim stands.

Chavan, Shekhar and Dr. Pimple Vandana (2016) stated that most of respondents of mediclaim policyholders are influenced by insurance agents and also concluded respondents prefer insurance policy along with banking facilities.

Kala, Sonal and Dr.Jain Premila (2015) in their research found that respondents were aware of health insurance but inspite of awareness, denied to purchase health insurance policy. People have much trust and confidence on Public much aware of terms and conditions of health insurance co. and they view that health insurance co. are not transparent.

Panchal .N (2013) concluded that most of the people don't have health insurance due to lack of information and income of people also plays pivotal role for purchasing of health insurance.

Objectives of the study:-Following are the main objectives of the research, they are as follows:-

- To know the relationship between gender and awareness through family.

- To know the relationship between age and awareness about the mediclaim policy through different sources.

- To know the effect of gender and income and investment in mediclaim policy for tax saving purpose.

\section{RESEARCH METHODOLOGY}

The study: The study undertaken is exploratory in nature and based on survey method.

The sample: The study conducted in Indore city. In the study there are 80 respondents who were the mediclaim policyholders of both the public and private insurance co. has been collected. During the survey, 90 questionnaires were distributed to respondents in Indore city. Unfortunately 10 questionnaires were not responded appropriately. So the relevant data is 
collected from 80 respondents, questionnaires based on dichotomous. Convenient technique was used to select the respondents.

Tool for Data collection: Primary data collected through self- structured designed close ended questionnaire. Secondary data from books, Internet, Journals, etc. has been collected.

Tool for Data Analysis: Total population of Indore is considered as finite were used for the study purpose. Statistics used like frequency distributions, graphs, charts and inferential statistics like chi square was implemented on the collected data. The data entry and analysis was performed by using Microsoft Excel and Statistical Package for Social Science (SPSS) version (21.0) and following test were conducted. In the study chi square test has been used.

Hypotheses:-The following hypotheses are formulated to test their validity in the context of above objectives:-

H01: There is no association between gender and awareness through family.

H11: There is an association between gender and awareness through family.

Result: From the chi- square distribution table, the value of chi square for 1 degree of freedom at 5\% level of significance is 3.841 . The calculated value of chi square is 10.716 which is more than the table value, indicating that null hypothesis is rejected.

Conclusion: Hence, it is concluded that there is an association between gender and awareness through family.

H02: There is no association between gender and investment in mediclaim policy for tax saving purpose.

H12: There is an association between gender and investment in mediclaim policy for tax saving purpose

Result: From the chi- square distribution table, the value of chi square for 1 degree of freedom at $5 \%$ level of significance is 3.841.The calculated value of chi square is 4.040 which is more than the table value, indicating that null hypothesis is rejected and our alternative hypothesis is accepted.

Conclusion: Hence, it is concluded that there is an association between gender and investment in mediclaim policy for tax saving purpose.

H03: There is no association between age and awareness through internet.

H13: There is an association between age and awareness through internet.

Result: From the chi- square distribution table, the value of chi square for 2 degree of freedom at 5\% level of significance is 5.991. The calculated value of chi square is 14.978 which is more than the table value, indicating that null hypothesis is rejected.

Conclusion: Hence, it is concluded that there is an association between age and awareness through internet as more youths are more relying on internet for information.

H04: There is no association between age and awareness through insurance agents.

H14: There is an association between age and awareness through insurance agents.

Result: From the chi- square distribution table, the value of chi square for 2 degree of freedom at $5 \%$ level of significance is 5.991. The calculated value of chi square is .760 which is less than the table value, indicating that null hypothesis is accepted.

Conclusion: Hence, it is concluded that there is no association between age and awareness through insurance agent. Insurance agents can make aware to any age group people.

H05: There is no association between age and awareness through banks.

H15: There is an association between age and awareness through banks. 
Result: From the chi- square distribution table, the value of chi square for 2 degree of freedom at 5\% level of significance is 5.991. The calculated value of chi square is 3.658 which is less than the table value, indicating that null hypothesis is accepted.

Conclusion: Hence, it is concluded that there is no association between age and awareness through banks.

H06: There is no association between age and awareness through family.

H16: There is no association between age and awareness through family.

Result: From the chi- square distribution table, the value of chi square for 2 degree of freedom at 5\% level of significance is 5.991.The calculated value of chi square is 1.189 which is less than the table value, indicating that null hypothesis is accepted.

Conclusion: Hence, it is analyzed that there is no association between age and awareness through family.

H07: There is no association between income and investment in mediclaim policy for tax saving purpose.

H17: There is an association between income and investment in mediclaim policy for tax saving purpose.

Result: From the chi- square distribution table, the value of chi square for 2 degree of freedom at $5 \%$ level of significance is 5.991. The calculated value of chi square is 7.182 which is more than the table value, indicating that null hypothesis is rejected.

Conclusion: Hence, it is analyzed that there is an association between income and investment for tax saving purpose. As with mediclaim they get safety, also can save the income tax by getting deduction of investment in mediclaim.

\section{LIMITATIONS OF THE STUDY}

- This study was conducted in Indore city only.

- Number of respondents could have more in study.

- This study was limited to mediclaim policy only, other health insurance could have been taken in the study.

\section{MANAGERIAL IMPLICATION}

In the survey, it is known that insurance agents plays an important role in making people aware for Mediclaim policy and now a days bank is also playing an imperative role in making people aware of mediclaim policy. So, insurance agents can be appointed in banks to convince those who still do not have policy. More advertisement on internet can be given regarding mediclaim, so more youth using internet can be approached .Not only awareness through internet is to be done, but integrated marketing communication has to be implemented, so people will be approached through every method of communication. Advertisement should endorsed with the help of celebrity and the message should focus how necessary it is for every one's life including that people can save their tax money through having mediclaim policy.

\section{CONCLUSION}

The research concludes that awareness program regarding, why medi claim policy is necessary for everyone should be conducted by Government, NGO's and Private sector's organization through each and every media. Then only people who have lack of information and knowledge in relation to this will be awake. Among different various sources internet, insurance agents, family and banks are playing very crucial role. 


\section{REFERENCE}

[1] Agarwal.O, Banking and Insurance. Himalaya Publishing House, 2011.

[2] Chavan, S. "A study on the Awareness about the Mediclaim Policy holders in Pune District". International Journal of Basic and Applied Science, 1 (4), (2016), pp 15 - 160.

[3] R. Calvin, Dr. P.T. Vijaya Rajakumar and Dr. G. Bhuvaneswari, Influence of Brand Equity Dimensions on Customer Purchase Intention - An Empirical Study in Indian Insurance Industry. Journal of Management, 5(4), 2018, pp. 432-437

[4] Gulati, C. N, Principles of Insurance management. New Delhi: Excel Books, 2010.

[5] A.Ramaraju, Health Insurance Scheme For Low Income Groups In India With A Focus On Urban Poor In Cochin, International Journal of Marketing and Human Resource Management (IJMHRM), Volume 6, Issue 1, January - April (2015).

[6] India, T. I., Banking and Insurance Law and Practice. New Delhi: Taxmann publications (P) Ltd, 2010.

[7] D. Dhanuraj, Health Insurance Scheme For Low Income Groups In India With A Focus On Urban Poor In Cochin, International Journal of Management (IJM), Volume 2, Issue 2, MayJuly (2011), pp. 182-197

[8] Kala, S. D. A Study on "Awareness of Health Insurance among People with special reference to Rajasthan -India". International Journal of Business Quantitative Economics and Applied management Research, 1(12) 2015, pp 21 - 31.

[9] Appanna K K and Vidya D Avadhani, Impact of Career Resilience on Job Performance among the Employes of Private Insurance Sector, International Journal of Mechanical Engineering and Technology 9(1), 2018. pp. 423-430.

[10] Kothari, C, Research Methodology and Techniques. New Delhi: New Age International (P) Limited, 2004.

[11] Nilay, P. Consumer's Perception towards Health Insurance: An Empirical Study in Bardoli \& Mandvi Region, Indian Journal of Applied Research, 3 (4), 2013, pp. 62 - 64.

[12] Priya, A. D. A Study on Customer Awareness towards Health Insurance with special Reference to Coimbatore City". IOSR Journal of Business Management. 17 (7),2015, pp 5054

[13] Sethi, J. a, Elements of Banking and Insurance. New Delhi: PHL Learning Private Limited, 2012.

[14] Singh, P. "Penetration of Health Insurance in India" Reality or Mirage. Research Journal of Business Management, 2018

[15] Uma, S, "Medical Utilization Practices Among the Patients of Private Hospitals in Coimbatore City ". Indian Journal of Research, 6 (11), 2017 